\title{
A crítica do narrador intelectual pingente:
}

\section{Lima Barreto evocado por João Antônio ${ }^{1}$}

\section{The criticism of the pingente intellectual narrator:}

\section{João Antônio evokes Lima Barreto}

\section{Por Cláudio Rodrigues Coração}

\section{Introdução}

Os afetos mobilizados pela atividade intelectual estão dispostos em quais valores e funcionalidades? Quais os propósitos da manifestação cultural interligados a esses afetos? Tais questões podem gerar outras tantas, no debate sobre como o intelectual se comporta em sua "função crítica", como uma espécie de mediador das tensões decorrentes de um comprometimento elementar: a angústia do pensamento diante de uma realidade externa incontrolável.

Partindo do pressuposto de que a atividade de pensar pode ser absorvida por meio da leitura de fenômenos dessa realidade incontrolável, nos interessa, aqui, de partida, compreender as tensões oriundas da forma de ler o mundo pelo prisma do intelectual. Poderíamos chamar esse movimento de veio crítico, preliminarmente. Para isso, mobilizaremos dois escritores-jornalistas, Lima Barreto (1881-1922) e João Antônio (1937-1996).

O escritor e jornalista João Antônio² lança, em 1977, o livro Calvário e porres do pingente Afonso Henriques de Lima Barreto, espécie de colagem de depoimentos tidos como reais, mas trabalhados como ficcionais, coletados de Carlos Alberto Nóbrega da Cunha, um interlocutor que teria percorrido junto ao escritor Lima Barreto, nas primeiras décadas do século XX, diversos pontos da cidade do Rio de Janeiro: em andanças, porres, cafés, desilusões. $O$ acompanhamento do narrador Nóbrega - em seu depoimento testemunhal - é organizado, sobretudo, na construção de uma atmosfera do trajeto melancólico de Lima Barreto, entre centro e subúrbio, representado como

\footnotetext{
1 Trabalho apresentado no XXVIII Encontro da Compós, em junho de 2019, em Porto Alegre

2 "A trajetória profissional de João Antônio caracteriza-se por um intenso trabalho literário e jornalístico e por declarações explosivas sobre a realidade brasileira e a situação da literatura nacional. Dividindo-se entre São Paulo e Rio de Janeiro, o autor escreve literatura e também reportagens para publicações de grande circulação" (MARTIN, 2008, p. 19).
} 
um intelectual andarilho, a percorrer, de maneira desconfortável, a geografia e a topografia da cidade, perdendo-se e confundindo-se com personagens e narradores reais e ficcionais, tanto do universo literário dele próprio, Lima Barreto, como de seus contemporâneos.

Calvário (no sentido de longo sofrimento, martírio), porres (no sentido de excessos decorrentes do consumo do álcool) e pingente (o passageiro que viaja pendurado na porta ou janela do transporte urbano) são expressões condicionadas a uma premissa norteadora com a qual o intelectual Lima Barreto se apresenta: não só o escritor (atormentado pelos seus dilemas e angústias pessoais ${ }^{3}$ ), mas fundamentalmente o marginal envolto nas absorções de seus personagens também marginais, e, sobretudo, na condição de andarilho urbano sufocado pelo processo intenso de modernização da cidade nos anos seguintes à abolição da escravidão. Essa é a tomada de posição da narrativa-colagem de Calvário e porres do pingente Afonso Henriques de Lima Barreto. Embalada, é importante dizer, pela força da edição de um depoimento testemunhal sobre o trajeto de sujeitos marginais no dia e a na noite de uma cidade ao mesmo tempo fantasmagórica e cintilante. A tradução dos percursos, metaforizada como calvário, evidencia uma proposição maior: a reflexão em torno do intelectual desassossegado com os delírios da modernidade do início do século XX, a encarar o trajeto cambaleante como elemento central desse desassossego em relação a uma pretensa "agenda civilizatória".

Assim, há uma distinção essencial. O trajeto desses sujeitos andarilhos é diferente do narrador flâneur. O pingente parece estar intensamente mergulhado na reflexão intelectual crítica, porque, diferentemente do narrador flâneur, impõe-se a ele o contato agudo com a realidade, além do entorpecimento da observação diante dessa mesma realidade. Na apresentação de Calvário e porres do pingente Afonso Henriques de Lima Barreto, João Antônio, no texto "Lima Barreto, um pingente", arremata:

Frente à dignidade de sua obra e vida, ambas pingentes, não se sabe que reverência não lhe será minguada, que homenagem não the será pobre e insuficiente. Sobre Lima, hoje [1977] atual e esquecido, distante dos nossos cursos de letras e de nossas escolas de comunicação, tenho ouvido algumas coisas significativas (...). Mas o esquecimento a que está atirada sua produção, me cansa. Do calvário e porres desse grande pingente suburbano, urbano, brasileiro e universal é possível extrair tanta coisa, que encabulo (...) um Rio suburbano ainda agora, como naquele tempo, esquecido; de uma arraia-miúda carioca de que talvez nunca mais se tenha tido notícia (...). De

\footnotetext{
3 "[Lima Barreto] retratou certos políticos e certos literatos como eram de fato: caricaturas de líderes e de intelectuais. Através de personagens-símbolos, traçou em seus romances todo o panorama da mentalidade burguesa, predominante no Brasil, nos primeiros trintas anos de nossa vida republicana. Recordações do Escrivão Isaías Caminha representa a luta não somente contra o preconceito de cor, mas contra a mediocridade, contra uma falsa concepção de imprensa e literatura, acompanhada da amarga experiência da vitória à custa de transigências de toda ordem e do sacrifício da própria dignidade humana" (BARBOSA, In: LIMA BARRETO, 1971, p. 13).
} 
Afonso Henriques de Lima Barreto está tudo aí, vivo, pulando, nas ruas, se mexendo, incrivelmente sem solução (JOÃO ANTÔNIO, 1977, p. 14).

Pois bem. Se contextualizarmos a produção de João Antônio, a partir do início dos anos 1960, situada na urgência filosófica da "rua se mexendo", mais especificamente no lançamento da coletânea de contos Malagueta, Perus e Bacanaço (1963), perceberemos em dedicatórias, menções, homenagens e citações que a presença de Lima Barreto em sua obra carrega uma espécie de obsessão. Em reproduzir por meio de uma assimilação intelectual determinados trajetos nas cidades (São Paulo e Rio de Janeiro, principalmente). Essa incorporação é elaborada pela/na figura do pingente, como um ser em contato íntimo com a realidade precarizada da "rua que se mexe". Duas representações surgem dessa reunião: a) o pária social, o "sem eira nem beira" do caldo urbano; b) o ressentido rancoroso, que não se adapta aos ventos da "modernização" do espaço urbano.

Em Calvário e porres do pingente Afonso Henriques de Lima Barreto, a montagem realizada por João Antônio, com os fragmentos dos textos literários e jornalísticos de Lima Barreto, mostra um mosaico de compreensão de um tipo de narrador: o narrador pingente. Se estamos dizendo que existe uma incorporação ética e estética entre os autores, precisaríamos também mover a crítica cultural - como conceito e manifestação - em torno dos impactos e significados dessa leitura para o campo da atividade literária, artística, comunicacional e midiática. Cuja premissa parece ser o posicionamento do intelectual a respeito do mundo que o circunda. Nesse sentido, é interessante observar o que nos diz Coelho (2006) sobre os limites do chamado engajamento intelectual: "Que haja limites "de classe", impedimentos ideológicos à ação de um intelectual burguês, mesmo quando sinceramente empenhado em lutar pela justiça e pela verdade é um truísmo (COELHO, In: NOVAES, 2006, p. 112)".

A máxima do "comprometimento literário de Sartre", também contextualizada por Coelho (2006), é componente necessário para a discussão sobre possível função da arte, em diversos contextos. A obsessão de aspecto autorreflexivo nos leva aos liames da produção de Lima Barreto como guia moral e estilístico do posicionamento intelectual (e literário) de João Antônio.

\footnotetext{
${ }^{4}$ A ideia do "comprometimento e engajamento literários", presente na obra "O que é a literatura", de Jean Paul Sartre, é trazida no ensaio de Marcelo Coelho para firmar a discussão a respeito do papel da atividade intelectual, no contexto pós Segunda Guerra Mundial.
} 


\section{Lima Barreto e o trajeto urbano: o narrador pingente}

Em torno do cronista Lima Barreto5, diz Beatriz Resende (2004): "A trajetória de Lima Barreto pela imprensa carioca termina por onde começou, na defesa da cidade, na crítica aos poderosos, na desconfiança diante das modificações que impunham à geografia da cidade" (RESENDE, In: RESENDE; VALENÇA, 2004, p. 22).

O que move o semblante e a fisionomia do escritor/jornalista é a do melancólico triste, combalido por sua condição racial, por seu comportamento antissocial, pelo consumo desregrado do álcool, na constante lida entre a aceitação e a rejeição dos espaços intelectuais da sociedade de seu tempo. Os personagens e narradores de Lima Barreto ${ }^{6}$ parecem transitar nesse mundo inadequado aos ares de uma pretensa modernização (dos costumes e da estrutura social da cidade), cujos desenlaces dos convívios, quase sempre irascíveis, formam o veio crítico. Os seus depoimentos mais pessoais giram em torno da constatação da crítica intelectual como proposta de manifestação cultural. O desconforto com o beletrismo (a escrita pomposa), por exemplo, presente em muitos de seus textos, molda uma natureza cultural irônica, a reparar o aspecto condicionante da formação intelectual do país e a relatar a educação sentimental autoprojetada desse intelectual, diríamos, orgânico e marginal. Nesse bojo, a vida social e intelectual precisa ser incorporada à andança, ao percurso, ao bonde lotado. Em cuja revelação se configura a formação da cidade do Rio de Janeiro, na Primeira República, além das marcas oficiais, e na percepção cruel da fragilidade e da condição do intelectual suburbano. Eis a crítica mais contundente de sua manifestação literária, portanto: o intelectual brasileiro é também um marginal.

Desse modo, personagens da sua ficção, como Policarpo Quaresma, Clara dos Anjos, Gonzaga de Sá, travestem-se de incômodas interações nos laços sociais, em meio à pressão já estampada da vida intelectual nos salões, nas academias de letras, na chancela social, no elitismo

\footnotetext{
5 "O antagonismo que Lima Barreto estabelece entre sua escrita e aquela coelhonetista [referência ao escritor Coelho Neto] para "fazer brindes de sobremesa, para satisfação dos ricaços" corresponde ao antagonismo que cresce entre bairros "aristocráticos", "civilizados", de "gente fina" e os subúrbios com sua burguesia e operariado que a sociedade clânica, clientelista, onde o favor predomina, expulsou em nome do progresso de seu cenário de "cartão-postal" para uma periferia desatendida pelo Estado. Nesse quadro, os verdadeiros atores da modernidade, como é a classe operária ou como são os artistas renovadores, não conseguem definir sua identidade como personagem da sociedade civil" (RESENDE, 2016, p. 19).

6 "A violência da sociedade brasileira que, pelo preconceito, restringe as possibilidades de vida aos negros e aos seus descendentes, está presente em toda a obra de Lima Barreto. Porém, o personagem paradigmático dessa condição é, sem sombra de dúvida, Isaías Caminha. Com esse romance, Lima Barreto pretendeu mostrar que "um rapaz nas condições de Isaías, com todas as disposições, pode falhar, não em virtude de suas qualidades intrínsecas, mas batido, esmagado, prensado pelo preconceito"' (MACHADO, 2002, p. 57).
} 
dos encontros. Tais personagens se moldam a outro caldo social, nessa espécie de demarcação simbólica de distinção na obra de Lima Barreto, a descrever o morador dos subúrbios, das periferias, dos morros cariocas. A confusão que se dá, de modo inevitável, entre a margem do convívio social e o centro da produção de uma cultura "legitimada" escancara as angústias e os preconceitos sofridos pelo sujeito-autor, em relação íntima com os narradores-personagens desvalidos, excluídos. Além disso, sua obra destaca a dor dos trajetos (tanto os espaciais quanto os temporais), por meio de um procedimento narrativo autorreflexivo, calcado na reminiscência e no depoimento, sejam eles pessoais, sociais ou ensaísticos.

O narrador pingente, na obra de Lima Barreto, é, reforçamos, contrastante ao narrador flâneur, se atentarmos às denominações do conceito/expressão a partir de Benjamin e sua leitura da obra de Charles Baudelaire (2018):

A rua conduz o flâneur em direção a um tempo que desapareceu. Para ele, qualquer rua é íngreme. Ela vai descendo, quando não em direção às Mães, pelo menos rumo a um passado que pode ser tão mais enfeitiçante por não ser seu próprio passado, seu passado particular. Entretanto, este parece sempre o tempo de uma infância. Mas por que o tempo de sua vida vivida? No asfalto sobre o qual caminha, seus passos despertam uma surpreendente ressonância. A iluminação a gás que recai sobre o calçamento lança uma luz ambígua sobre este duplo chão. Uma embriaguez apoderase daquele que, por um longo tempo, caminha a esmo pelas ruas (BENJAMIN, 2018, p. 702).

Quem talvez tenha manifestado essa essência, esse espírito benjaminiano da embriaguez do flâneur, foi o contemporâneo de Lima Barreto, João do Rio (Paulo Barreto), que, em "A rua" (2008), propõe um ensaio medido na seguinte observação: "o flâneur perambula e observa a rua com espírito vagabundo".

Em Lima Barreto, os apuros da cidade moderna se medem em outras preocupações que não apenas o "delírio", o "feitiço", a "embriaguez", a "sedução" das imagens. Nas crônicas citadinas examinadas por Resende e Valença ${ }^{7}$, observa-se que o trajeto pingente antecipa uma discussão sobre a reportagem jornalística, em distinção com o olhar "vagabundo", preconizado por João do Rio, como foco narrativo de repórter intrépido. Além disso, identifica-se uma tomada de realidade por meio de uma postura intelectual de contato íntimo. Ora, se estas tensões, reveladas a partir de distinções e de contatos com a vida social, orientam as narrativas, o desnudar do ambiente se dá de modo quase sempre instável, pois há o desajuste do trajeto, por si só, a moldar o percurso

${ }^{7}$ RESENDE, Beatriz; VALENÇA, Rachel. Lima Barreto: Toda Crônica. volume 1: 1890-1919. Rio de Janeiro: Agir, 2004. 


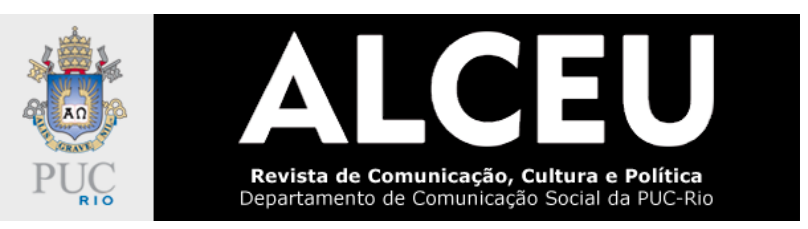

narrativo e a afirmar o discurso como veio crítico social. Portanto, não se trata, somente, de um percurso entorpecido pela observação desapegada de flâneur.

O exemplo da ideia filosófica de "comprometimento" do narrador pingente, em Lima Barreto, pode ser notado nas peripécias do narrador Isaías Caminha, de Recordações do Escrivão Isaías Caminha, publicado originalmente em 1908. O romance sobre o jovem que vem do interior e se depara com um universo hostil à sua origem de rapaz tímido e introvertido elucida uma série de questões inerentes ao significado ampliado do seu trajeto de vida.

Toda a fauna humana, especialmente o universo da redação do jornal O Globo, lidada pelo narrador, demonstra atividades intelectuais corrompidas na ambiência das relações públicas e privadas, e evidencia o jornalista como agente mediador - e legitimador - de outros atores sociais da Primeira República, a partir da natureza desses encontros e desencontros, firmados nessas relações de forças. O narrador Caminha descreve o avanço do mundo capitalista devorador, a lhe sugar as aspirações passo a passo, e lhe exigir a derrocada, como se sua resignação fosse condicionando seu percurso de vida com atributo marginal e pingente. Nesse sentido, o suporte da narrativa do romance é o da redenção pesarosa. Assim, Caminha (cf. BOSI, 2002) se vê envolto em etapas de superação e rupturas: o "eu enfurnado", o "eu desejoso", o "eu reprimido", o "eu narrador satírico", o "eu crítico", o "eu resignado".

O processo desse narrador pingente, na profissão que exerce, no contato com seus interlocutores adversários e aliados, está ancorado na vida social e em seus jogos de retaliação e distinção: o legitimado x o desvalido. O olhar interno da atividade intelectual, ou o anseio de vida do narrador, lança Caminha como crítico do exame do intelectual de seu tempo - os literatos, os jornalistas, a elite econômica, os "doutores" - descrevendo-os como figuras movidas pelo compadrio e pelo beletrismo. Em Os Bruzundangas, publicado postumamente em 1923, espécie de ensaio satírico da sociedade brasileira, o narrador provoca:

Os literatos, propriamente, aqueles de bons vestuários e ademanes de encomenda, não lhe dão importância, embora de todo não desprezam a literatura oral. Ao contrário: todos eles quase não têm propriamente obras escritas; a bagagem deles conta de conferências, poesias recitadas nas salas, máximas pronunciadas na intimidade de amigos, discursos em batizados ou casamentos, em banquetes de figurões ou em cerimônias escolares, cifrando-se, as mais das vezes, a sua obra escrita em uma plaquette de fantasias de menino, coletâneas de ligeiros artigos de jornal ou num maçudo compêndio de aula, vendidos, na nossa moeda, à razão de quinze ou vinte mil-réis o volume. Estes tais são até os escritores mais estimados e representativos, sobretudo quando empregam palavras obsoletas e são médicos com larga freguesia (LIMA BARRETO, 1998, p. 16). 
Percebemos que a obra de Lima Barreto se baliza, portanto, nas seguintes características: a) crítica ao beletrismo; b) angústia reflexiva e pessoal; c) postura marginal; d) condição ancorada fora dos espaços intelectuais; a rua, fundamentalmente.

O último item parece resumir a estética do narrador pingente, mas esse componente, a rua, só pode ser examinado se disposto com os outros três. Ou seja, o narrador pingente é um ser condicionado pela violência do "inferno citadino", a lhe endossar a postura marginal e reflexiva.

O que João Antônio costura em seu Calvário e porres do pingente Afonso Henriques de Lima Barreto é, portanto, uma síntese dessas características, elaborando uma espécie de controle das nuances das discussões intelectuais, críticas e estéticas. Observa-se, na leitura de João Antônio, o olhar de compreensão da obra de Lima Barreto, a firmar, de maneira elogiosa, a condição do narrador pingente:

Demorava-se como os outros, no máximo, das três às cinco da tarde no barzinho da rua Sachet. Depois, tomavam seus itinerários. Mas ele era pontual à roda de Coelho Cavalcanti, visto que ia diretamente entregar sua colaboração à Careta. Mandava-se da rua Sachet. Tomava a Avenida Rio Branco e geralmente ia só, que na roda da Sachet apenas ele era suburbano (...). A maioria era do Catete, Cidade Nova ou bairros como Santa Alexandrina, São Cristóvão, Itapagipe, Itapiru, Rio Comprido, Matoso. E não poucos eram de Niterói, vindos de lá atravessando a Baía. Maioria morava em bairros acessíveis por bondes elétricos. Lima ia de trem, que apanhava na Central, descia em Todos os Santos e da lá tocava até Inhaúma (JOÃO ANTÔNIO, 1977, p. 30).

A evidência desse narrador pingente está atrelada, a nosso ver, às inconstâncias do próprio trajeto para o distante subúrbio, evidentemente, que exige dele um mergulho de projeção áspera. No caso específico de Lima Barreto, isso se traduz nas experiências pessoais (o escritor incompreendido, o jornalista crítico e mordaz) quando se denota nas linhas dessa percepção o trajeto reflexivo pingente até a sua morada em Inhaúma.

Inserido em um momento e em um espaço na periferia, em que se consolida a formação da sociedade capitalista, Lima Barreto promove (...) a autocertificação dessa modernidade periférica e tardia pelo prisma da literatura. Surge aqui, tal como nos porta-vozes originais, o desenvolvimento de uma nova linguagem: uma linguagem que atende mais de perto à alma e ao corpo da modernidade brasileira. Como Baudelaire, Lima Barreto estava preocupado em desenvolver uma linguagem mais adequada à realidade de seu tempo. Mas, ao contrário do poeta francês, não desejava uma linguagem adaptada aos impulsos líricos da alma, ou às modulações do sonho, ou aos saltos e sobressaltos da consciência. Compreendendo a literatura como um instrumento de comunhão e união entre os homens, desejava uma linguagem que denunciasse os entraves sociais ao congraçamento humano (MACHADO, 2002, p. 91).

A descrição de Machado (2002) nos esclarece com mais elementos a distinção do flâneur com o pingente, pois evidencia que a marginalidade da vida social também é observada/percebida 
pelo narrador. E se esse narrador estiver condicionado àquele inferno de proporções desajustadas, exige-se a ele uma percepção pingente: o ruído das ruas, o tropel, a deterioração social.

Nesse sentido, a atividade intelectual estaria dimensionada na tensão crítica do pingente, como uma espécie de observador silencioso, mas não menos incisivo. Segundo Antonio Cícero (2004):

Para o intolerante, o intelectual tolerante ou relativista, que age desse modo [no silêncio de observador], não passa de um fraco, a quem falta caráter, convicção ou fé. Não é difícil perceber que as consequências disso podem vir a ser catastróficas, num mundo em que os fundamentalismos religiosos têm se tornado cada vez mais comuns (CíCERO, In: NOVAES, 2006, p. 204).

A partir da constatação de Cícero podemos dar um próximo passo aqui, na tentativa de descrever os elementos da configuração do que viria a ser o intelectual pingente em sua extensão com o narrador pingente.

\section{Intelectual pingente: angústias, projeções e resistência}

Os samoiedas [espécie de literato pomposo] contentam-se com as aparências literárias e banal simulação de notoriedade, umas vezes por incapacidade de inteligência, em outras por instrução insuficiente ou viciada, quase sempre, porém, por falta de verdadeiro talento poético, de sinceridade, e necessidade, portanto, de disfarçar os defeitos como pelotiquices e passe de mágica intelectuais (LIMA BARRETO, 1998, p. 17-18).

O público que nos lê, não sabe o quanto essa vida de jornalista é esgotante e ingrata; não sabe que soma de energia ela exige e como nos tira os melhores momentos de ócio e os melhores minutos de prazer. Vivemos por assim dizer para os outros; e quem vive para os outros, é claro que muito pouco pode viver para si (LIMA BARRETO, 1971, p. 169).

A partir desses dois fragmentos (o primeiro retirado de Os Bruzundangas, o segundo de Recordações do Escrivão Isaías Caminha), podemos observar que existe uma vontade, por parte dos respectivos narradores, em afirmar os desapontamentos com a atividade intelectual. Esse posicionamento é feito de certo ressentimento, cuja premissa precisa ser abordada como instrumento mediador dos diversos significados em torno da atividade intelectual.

Assim, é preciso seguir em duas direções para compreendermos as minúcias desse processo de categorização do intelectual pingente. Ao que parece, existe nessa discussão uma inseparabilidade entre o autor intelectual, envolvido pela crítica interna do aparato literário, e a dinâmica de reconhecimento da realidade como parte de um desejo de questionamento do beletrismo cultural. 


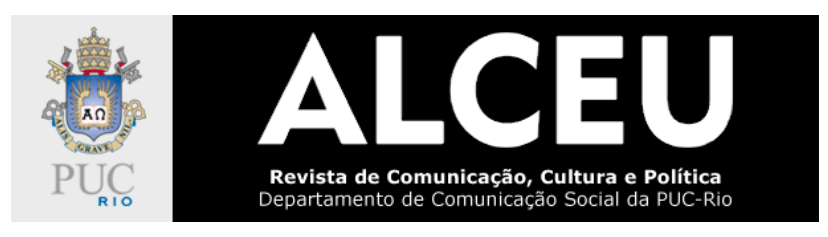

Se podemos aferir a crítica como esteio do reconhecimento da mediação intelectual, estamos evidentemente atribuindo um valor (e uma funcionalidade) a essa disposição, cuja neutralidade também tem de ser questionada. Demonstra-se, por exemplo, tanto na sátira de Os Bruzundangas como no romance Recordações do Escrivão Isaías Caminha, uma espécie de busca de compreensão intelectual, por meio de uma crítica interna à descrição de dada caricatura do mundo intelectual da Primeira República, a revestir o narrador pingente como categoria estética, como fiador da resistência da angústia corrente: a inadequação e inadaptação do escritor marginal a determinadas rodas sociais.

A partir das questões presentes na obra de Lima Barreto aqui destacadas, nota-se que o intelectual pingente se orienta numa correlação de forças, a mediar o simbólico presente nos meios de transporte, na comunicação, na literatura e na relevância da própria intelectualidade materializada na cidade. Como podemos perceber na crônica "Quem será, afinal?", publicada no jornal ABC em 15/01/1919:

Compreendo perfeitamente esse estado de espírito policial ou costumeiro, à vista da carestia de vida e da necessidade em que está o literato que quer ter fama de não dizer nada, andar bem-vestido e fazer parte da corte de algum Cunhambemba político. Não sou desse figurino e sei que irrito os altos espíritos dos manequins intelectuais, quando me veem o nome com qualquer apelido literário. Adivinho o que eles dizem; e os melhores, os de bofe menos maus, hão de refletir assim consigo mesmo: - Este Barreto é louco! (LIMA BARRETO, In: RESENDE; VALENÇA, 2004, p. 450).

Estabelece-se aqui o desassossego da localização do tempo e do espaço do intelectual pingente, que se manifesta no cronista imbuído do sentimento da projeção: o louco marginal inadaptado.

O arremate da discussão em torno da intelectualidade em Lima Barreto, a nosso ver, empreende, de modo original, uma crítica interna aos valores de uma dada produção cultural formal. Em outra crônica, “As escoras sabichonas”, publicada em abril de 1919”, diz:

Onde buscá-lo [os eruditos]? No Senado? Na Câmara? Não. Era vulgar. Foi buscá-lo nas letras. Ah! As letras! Todos as desdenham e todos querem a glória que elas dão. Os que se entregam a elas, merecem dos homens sisudos e sábios os piores epítetos e qualificativos. Os menores são devassos, bêbados e ignorantes... Mas não há nenhum sujeito que tenha aprendido a ler, que tenha escrito uma carta à namorada, que tenha redigido uma reclamação aos jornais, que não se julgue literato e afilhado das Musas (LIMA BARRETO, In: RESENDE; VALENÇA, 2004, p. 511).

Se não repararmos nas sutilezas da tensão desse fio do intelectual pingente amargurado, talvez não reconheçamos o valor de crítica a um atributo intelectual. Ou seja, ser pingente é ser gauche na vida, é estar à margem do encontro ritualístico da própria atividade intelectual, em suma. 
Se Benjamin investe no semblante da melancolia a identificar as aparências da verve moderna do flâneur, é justamente por esse paradoxo que poderíamos enxergar os principais valores revelados como crítica na disposição do intelectual pingente.

Há em Lima Barreto, ao certo, uma oposição a João do Rio (o flâneur). A leitura de João Antônio como mediação (em Calvário e porres do pingente Afonso Henriques de Lima Barreto) atribui, a partir dessa distinção, condicionante elogioso à figura do pingente e sintetiza a crítica à modernidade dita civilizatória, evocando certo tradicionalismo pueril (suas lembranças pessoais do futebol, das rodas de choro da infância). A crítica intelectual projetada no pingente é a afirmação de uma condição (o marginal cambaleante na rua).

Então, na extensão do que estamos desenvolvendo como ideia central de mediação, o modo com que João Antônio elabora a narrativa pingente com a crítica, por meio da evocação de Lima Barreto, é parte central na disputa em torno da atividade intelectual. O martírio relatado do personagem depoente Carlos Nóbrega, em Calvário e porres do pingente Afonso Henriques de Lima Barreto, é o fio da mediação, nesse sentido. É como se ela desenvolvesse, primeiramente, a descrição espaço temporal, e estabelecesse posteriormente uma espécie de sistematização da atividade intelectual pingente.

Diante disso, a leitura de João Antônio percebe a crítica como componente de fundo, a todo o momento. O que Calvário e porres do pingente Afonso Henriques de Lima Barreto parece validar é justamente a potência literária empreendida por Lima Barreto em seu tempo: como autor corrosivo do início do século XX, e assimilado em condição de resistência para o intelectual brasileiro nos anos 1970.

\section{Cabe aqui um parêntese.}

Scott (2018), em texto publicado pela revista serrote, diz:

O grande falsificador do juízo crítico é o tempo. Esse é outro modo de afirmar que a maneira mais segura de estar errado é dizer absolutamente qualquer coisa. Um crítico empenhado em farejar o novo está, por definição, deslumbrado pelo presente. O fulgor da obra que acaba de ser vista pode ser ofuscada, e o que talvez venha a se revelar como uma fachada barata e cafona de novidade pode parecer, no calor do entusiasmo pela descoberta, uma coisa autenticamente revolucionária. Ou, inversamente, sua aparente insipidez será na verdade uma pátina temporária e obscurecer seu verdadeiro brilho, que só se revelará a olhos futuros (SCOTT, 2018, p. 201).

É interessante notar que o crítico - compreendido aqui como aquele que trabalha em mídia, mas também o acadêmico universitário, o escritor - é interlocutor dos salões da produção cultural, em suas variadas teias de relação e recepção. Scott examina, em resumo, a potência da 
inevitabilidade de errar e o anseio crítico ideal a partir disso, na apreciação do objeto artístico ou cultural. Não deixa de ser curiosa a definição da crítica ideal que Scott lança. Cremos que essa disposição se assemelha à tensão envolvida no trajeto do intelectual pingente, em sua "imperfeição" autorreflexiva, no tempo e no lugar.

Voltando à discussão, percebe-se que os narradores da obra de Lima Barreto, identificados em Calvário e porres do pingente Afonso Henriques de Lima Barreto, são movidos pelo limite entre a dignidade identitária e as projeções sufocantes dessa identidade. E isso se dá no trajeto citadino, no percurso (espacial e temporal). Esse movimento, antes de tudo, é errante, mas não de um errar onírico, como o do flâneur. Tal significado é importante para percebermos o aspecto desejoso do pingente. Com isso, nota-se, além da evidência naturalista-realista e da crítica social revelada, a compreensão da marca de uma crítica intelectual pingente.

\section{O pingente é um crítico?}

Para Silva e Soares (2013):

Na crítica de mídias, valores são dinamicamente transformados nos repertórios por ela constituídos e nas reapropriações de tais repertórios ao sabor do gosto popular visando à formação de juízos. Nas tensões entre o estabelecimento de "valores" e a constituição de "repertórios", portanto, antigas distinções de "gosto" (erudito, popular, massivo, midiático) são desafiadas por meio da crítica contemporânea, a exemplo das contribuições de teóricos que destacam a importância dessas interações (SILVA; SOARES, 2013, p. 832).

Em cima desse raciocínio podemos dizer que a crítica de mídias pode ser endereçada, neste estado da arte, a partir da leitura de João Antônio em Lima Barreto, ao próprio desejo das possibilidades da metacrítica, por exemplo, e às reapropriações dos repertórios. Se pensarmos a obra dos dois autores, aqui postas em diálogo, notamos que uma ampla tradição da produção cultural brasileira, na literatura, no jornalismo, na música popular etc., estampa a tensão acerca da intelectualidade como crítica cultural autorreflexiva.

Não seria exagero pensar, portanto, que o pingente é um "crítico de mídia" original, pois se desloca, ante as aspirações na frequência dos salões, ou dos meios de comunicação de massa, junto a um dado espírito de contestação social. Eis um trecho de Recordações do Escrivão Isaías Caminha que parece sintetizar tal "espírito crítico" por parte do narrador: 
Eu tinha cem mil-réis por mês. Vivia satisfeito e as minhas ambições pareciam assentes. Não fora só a miséria passada que assim me fizera; fora também a ambiência hostil, a certeza de que um passo para diante me custava grandes dores, fortes humilhações, ofensas terríveis. Relembrava-me da minha vida anterior; sentia ainda muito abertos os ferimentos que aquele choque com o mundo me causara. Sem os achar, em consciência, justos, acovardava-me diante da perspectiva de novas dores e apavorei-me diante da imagem de novas torturas. Considerei-me feliz no lugar de contínuo da redação do $O$ Globo. Tinha atravessado um grande braço de mar, agarrara-me a um ilhéu e não tinha coragem de nadar de novo para a terra firme que barrava o horizonte a algumas centenas de metros. Os mariscos bastavam-me e os insetos já se me tinham feito a grossa pele (LIMA BARRETO, 1971, p. 117).

Nessas elaborações poderíamos retomar a natureza do narrador pingente (a crítica ao beletrismo, a reflexão pessoal e a postura marginal) e compor um quadro de crítica fundamentada pela função, pelo juízo e pelo valor (cf. SILVA; SOARES, 2013).

Então, chegamos a um atributo essencial em nosso exame: não há como identificar o narrador pingente dissociado da atividade crítica inerente à função social do intelectual, sendo ele pingente ou não. O comprometimento literário e artístico, portanto, é parte inconteste dessa elaboração. O jornalismo, em aproximação com a literatura, desnuda um valor cultural, no caso específico do narrador Isaías Caminha: a frivolidade da produção de informação, o campo miúdo dos espetáculos, a vida artística e suas armadilhas de sedução etc.

A angústia do narrador Caminha assemelha-se, portanto, ao próprio trajeto de Lima Barreto como sujeito público, no trânsito pingente: pendurado, frágil, combalido pela hegemonia do capital cultural dos beletristas. Resende (2016), a respeito, aponta que:

A questão da fragmentação [da cidade], na verdade, diz respeito à organização da cidade tal como ela perdura até hoje. A cidade fragmenta-se em espaços diversos, guardando entre si diferenças tão grandes como cidades diversas guardariam entre elas. No interior da cidade que os letrados buscam organizar, crescem duas cidades, a cidade ideal e a cidade real. A cidade ideal, dos cartões-postais e das revistas ilustradas, quer ocultar a cidade real, empurrando para os morros e subúrbios os figurantes indesejáveis (RESENDE, 2016, p. 99).

O aspecto acerca da fragmentação urbana desenhado por Resende é esclarecedor para observarmos a leitura das aspirações que João Antônio faz de Lima Barreto, no que se refere à "cidade fragmentária" (já no final do século XX). Mas antes disso é preciso afirmar uma ideia propositiva. A crítica do intelectual pingente é a observação da realidade e o discurso da própria produção intelectual ensejada nas tensões dessa observação atuante. Assim, interessa-nos, a partir da produção aqui destacada de Lima Barreto, empreender uma extensão, que tem a ver, necessariamente, com os ecos da leitura de Lima Barreto por João Antônio. 


\section{Ecos do narrador intelectual pingente: Lima Barreto em João Antônio}

No ensaio "Corpo a corpo com vida", de 1975, João Antônio propõe:

Precisamos de uma literatura? Precisamos. Mas de uma arte literária, como de um teatro, de um cinema, de um jornalismo que firam, penetrem, compreendam, exponham, descarnem as nossas áreas de vida (...). O caminho é claro, e, também por isso, difícil - sem grandes mistérios e escolas. Um corpo-a-corpo com a vida brasileira. Uma literatura que se rale nos fatos e não que rele neles. Nisso, a sua principal missão - ser a estratificação da vida de um povo e participar da melhoria e da modificação desse povo. Corpo-a-corpo. A briga é essa. Ou nenhuma (JOÃO ANTÔNIO, 1975, p. 145-146).

A ideia do corpo a corpo com a vida é interessante para arrematarmos a concepção de resistência literária presente no narrador pingente. Senão vejamos. João Antônio, em sua produção jornalístico-literária, de 1963 a 1996, trabalhou o engajamento literário - e jornalístico - a pautar temas e universos ligados aos desvalidos ("uma literatura que se rale nos fatos"). Assim, seu universo norteia a figura do intelectual como um marginal: "Sua obra [de Lima Barreto] até hoje é uma porrada, seca e rente, na nossa apatia, malemolência, calhordice, omissão, indiferença, farisaísmo, relapsia e macaqueação dos modelos estrangeiros. Qualidades igualmente pingentes" (JOÃO ANTÔNIO, 1977, p. 14).

Ora, há nessa entrega, em torno do corpo a corpo com a vida, uma ideia medida pelo contato físico, em que Lima Barreto é norte. No conto reportagem "Abraçado ao meu rancor", publicado originalmente em 1986, talvez a narrativa mais direta no que se refere às ideias propostas pela leitura de João Antonio de Lima Barreto, deparamo-nos com um narrador jornalista cansado do tédio da cobertura de cidades para o jornal O Estado de S. Paulo, entediado com o contato o pequeno mundo da produção cultural da cidade de São Paulo; tal sujeito desloca-se de um campo a outro da cidade para um fim (no caso, o trajeto do bairro Pinheiros até a chegada ao Morro da Geada, no município de Osasco, para visitar a mãe). Neste outro "calvário", o corpo a corpo se evidencia assim:

Tinha medo de arriar, dormir, perder a estação em que havia de descer. Era o último trem; e se dormisse? Apertados, uns nos apoiamos nos outros, no balanço das curvas balangamos todos. Os pingentes, lá fora, tomam vento frio na cara. Não podendo nos segurar em nada, nos firmamos em pé, sem cair, embora o trem jogue, e chegamos à Lapa. Um trem desses para. Empaca e atrasa. $O$ pessoal aguenta um aguenta dois. Correm a mão no pedregulho da estrada. Pudessem virariam a tralha de rodas para o ar. Quem tiver juízo saia da frente desse povo. Ninguém seja besta (JOÃO ANTONIO, 2001, p. 121).

É possível dizer que as bases teórico-metodológicas, digamos, do comportamento pingente estejam diluídas no canto melancólico de João Antônio, em "Abraçado ao meu rancor" nesse 
percurso de rua em rua, de trem em trem. Essa orientação biográfica é colocada em paralelo à figura de Lima Barreto, como uma projeção de sua própria identidade. De modo que a caracterização de sua personalidade se estabelece no mapeamento de alguns temas ligados a certa marginalia noturna (jogadores de sinuca, prostitutas, ex-jogadores de futebol), sempre na evidência do trajeto melancólico desses atores.

A reflexão do narrador de "Abraçado ao meu rancor" é sugestiva neste aspecto porque compreende as expectativas do intelectual pingente em outros textos. Essa elaboração aurorreflexiva é dolorosa, como podemos perceber no seguinte trecho:

Penei a infância aqui, nestas filas e trens encardidos, apinhados. Olhem, isso me bole. Daqui me saí, bandeei no mundo. Quando volto ao morro, quantas vezes, é subindo feito cabrito escabriado, meio na culpa, de assim... mas também com alegria, porque o pessoal diz, mal das coisas e me olhando as roupas, que sou feliz como um desgraçado (JOÃO ANTÔNIO, 2001, p. 122).

Portanto, evidencia-se a sedimentação da crítica intelectual pingente como proposta estética, a amarrar marcas presentes na literatura de Lima Barreto como base moral, como esteio. O encontro de João Antônio com Lima Barreto materializa-se, assim, nas seguintes constatações: a) O contato doloroso do pingente com a realidade social; b) A angústia inerente do marginal intelectual; c) A melancolia combativa.

Apropriando-se de Martin (2002), a combatividade melancólica, se associarmos com as nuances estabelecidas em Calvário e porres do pingente Afonso Henriques de Lima Barreto, é a de um intelectual pingente, delineador da modernidade e suas crises: o aumento urbano, a precarização da vida, a não compreensão nas representações do aparato da produção cultural massiva etc.

Essas bases ditam o procedimento de combatividade melancólica, vamos assim dizer. É próprio de Calvário e porres do pingente Afonso Henriques de Lima Barreto, portanto, a extensão da ideia do corpo a corpo com a vida. A síntese da montagem do texto e a observação do confidente Carlos Nóbrega estabelecem modelo metodológico dos procedimentos (externos e internos) do intelectual pingente, cujas balizas narrativas são a observação, o fluxo, a percepção e a ação.

Aqui não se trata, obviamente, de estabelecer uma classificação definitiva das intenções mais subjetivas dos narradores, mas esses dados gerais corroboram com os propósitos da produção jornalística e literária dos anos 1970, contexto das proposições ensaísticas de João Antônio sobre a literatura e do jornalismo (o fenômeno do romance-reportagem, mais especialmente). Essa disputa de sentido de realidade - ou de realismo - está ancorada na 


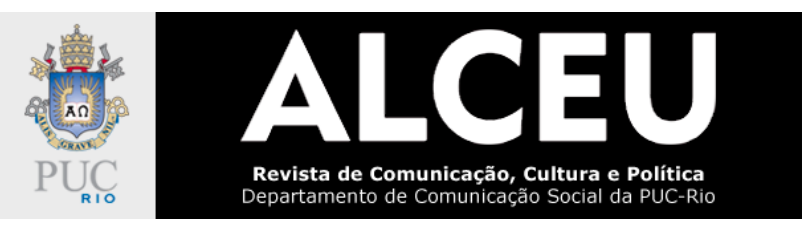

mediação de base ou na crítica como instrumento verificador de uma realidade nacional deteriorada.

É importante destacar, portanto, que existe um eco das manifestações em torno da proposta de crítica do intelectual narrador pingente. A leitura de João Antônio da obra de Lima Barreto pode ser compreendida na articulação de outras análises contemporâneas. Os vários tipos apreciados em Os Bruzundangas e Recordações do Escrivão Isaías Caminha reaparecem em João Antônio, de modo a estabelecer o intelectual beletrista como um antagonista das "causas" pingentes.

Nesse sentido, é curioso observar uma das frases mais pertinentes de "Abraçado ao meu rancor" para esse fim: a cidade deu em outra (a cidade que o narrador percorre e vê não é a cidade de suas rememorações, esta purificada por uma concepção de malandragem, de comunhão).

Há na percepção de presenças fantasmáticas, de pessoas com quem o narrador conviveu, o semblante de uma humanidade que se esvai. Esse saudosismo ingênuo é pista, muitas vezes, da ruminação da figura biográfica, em alguns casos. ${ }^{8}$

Não é impreciso dizer que as agruras do narrador Caminha, por exemplo, se ancoram nas agruras do narrador jornalista de "Abraçado ao meu rancor". Esse desenho do ponto de chegada sem casa - a errância - é um dispositivo da própria narração que não pode ser ignorado. Desse modo, a antirredenção é um atributo tão decisivo para se elaborar tanta presença crítica no século $\mathrm{XX}$, em que o narrador intelectual pingente se manifesta.

Podemos afirmar que há a necessidade de um mapeamento maior de tais manifestações, em várias frentes, cujo principal emblema, lançamos aqui, no final de nosso texto, é o trem: a estrada de ferro e a locomotiva envolvidos na ideia que permeia e contamina a produção cultural, desde a modernidade, em todo o século XX: no cinema, na literatura, no jornalismo, na música popular. Acreditamos que essa categoria, o trem, no mais, possa nos dar elementos consistentes de observação para que, por meio de sua ancoragem simbólica, identifiquemos algo essencial no trânsito de percurso do choque com a realidade: a percepção crítica menos como a constatação etérea e lírica do mergulho da modernidade, e mais como um grito de desconforto do próprio fazer crítico, no cambalear nos tempos e lugares dessa modernidade.

\footnotetext{
8 "Entendemos que os textos autobiográficos são parte da obra literária do autor, cumprem função decisiva em sua constituição enquanto escritor e, por fim, também expressam os limites literários de João Antônio, ligados, como não poderia deixar de ser, a questões de sua biografia" (ZENI, 2016, p. 32).
} 
Nesse sentido, o narrador pingente é uma espécie de ser metacrítico valioso, em permanente fruição, tensão e pulsão. Já que traz possíveis respostas para afetos mobilizados pela atividade intelectual. O encontro de Lima Barreto e João Antônio é um exemplo disso.

Cláudio Rodrigues Coração Professor do Programa de Pós-Graduação em Comunicação e do curso de Jornalismo da UFOP Doutor em Comunicação: Meios e Processos Audiovisuais pela ECA/USP ORCID: https://orcid.org/0000-0002-1402-7787 E-mail:crcorao@gmail.com

Recebido em: 02 de outubro de 2019.

Aprovado em: 27 de novembro de 2019.

\section{Referências}

BENJAMIN, Walter. Passagens. Tradução de Irene Bolle e Cleonice Paes Barreto Mourão. Belo Horizonte: UFMG, 2018.

BOSI, Alfredo. Literatura e resistência. São Paulo: Companhia das letras, 2002.

CICERO, Antonio. A sedução relativa. In: NOVAES, Adauto. O silêncio dos intelectuais. São Paulo: Companhia das letras, 2006.

COELHO, Marcelo. Engajamento e traição. In: NOVAES, Adauto. O silêncio dos intelectuais. São Paulo: Companhia das letras, 2006.

JOÃO ANTÔNIO. Calvário e porres do pingente Afonso Henriques de Lima Barreto. Rio de Janeiro: Civilização Brasileira, 1977.

. Abraçado ao meu rancor. São Paulo: Cosac \& Naify, 2001.

Brasileira, 1975.

Corpo-a-corpo com a vida. In: Malhação do Judas Carioca. Rio de Janeiro: Civilização JOÃO DO RIO. A alma encantadora das ruas. São Paulo: Companhia das letras, 2008.

LIMA BARRETO. Recordações do Escrivão Isaías Caminha. 5.ed. São Paulo: Brasiliense, 1971.

Os Bruzundangas. Porto Alegre: L\&PM, 1998.

MACHADO, Maria Cristina Teixeira. Lima Barreto: um pensador social na Primeira República. Goiânia; São Paulo: UFG; EDUSP, 2002.

MARTIN, Vima Lia. Literatura e marginalidade. São Paulo: Alameda, 2008. 


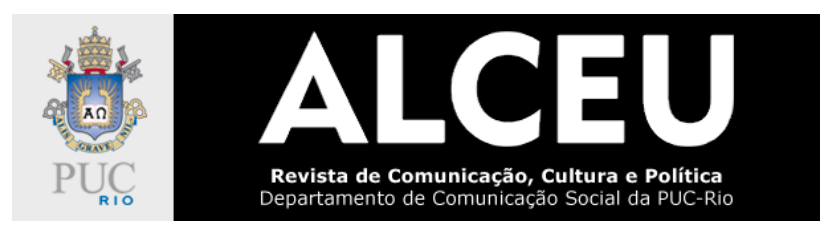

RESENDE, Beatriz. Lima Barreto e o Rio de Janeiro em fragmentos. Belo Horizonte, Autêntica, 2016.

RESENDE, Beatriz; VALENÇA, Rachel. Lima Barreto: Toda Crônica. volume 1: 1890-1919. Rio de Janeiro: Agir, 2004.

SCOTT, A. O. Como estar errado. Tradução de José Geraldo Couto. São Paulo: Revista Serrote, n.29, IMS, 2018.

SERELLE, Marcio. A ética da mediação: aspectos da crítica da mídia em Roger Silverstone, São Paulo: Revista Matrizes, 2016.

SILVA, Gislene; SOARES, Rosana de Lima. Para pensar a crítica de mídias. Porto Alegre: Revista Famecos, 2013.

ZENI, Bruno. Sinuca de malandro: ficção e autobiografia em João Antônio. São Paulo: EDUSP, 2016.

\section{Resumo}

Pretendemos examinar as manifestações expostas pelo narrador intelectual pingente, a partir de textos literários e jornalísticos de Lima Barreto (1881-1922). O eco crítico de tal exame pode ser percebido na obra do escritor e jornalista João Antônio (1937-1996), especialmente em Calvário e porres do pingente Afonso Henriques de Lima Barreto (1977). Nosso percurso pretende articular tais textos por meio da descrição, discussão e análise da crítica firmada como elemento decisivo para os propósitos desse narrador intelectual pingente, considerando os aspectos de mediação e de valores culturais no diálogo entre os dois autores. Para isso, utilizaremos referenciais teóricos que possam nos dar pistas sobre a reflexão da crítica como fenômeno intelectual, comunicacional e artístico.

Palavras-chave: Crítica. Narrador Intelectual Pingente. Lima Barreto.

\section{Abstract}

We intend to assess manifestations addressed to' narrador intelectual pingente', from literary and journalistic texts of Lima Barreto (1881-1922). The critical echo of such assessment can be seen in the work of the writer and journalist João Antônio (1937-1996), especially in Calvário and Porres do pingente Afonso Henriques de Lima Barreto (1977). We intend to articulated such texts by means of description, discussion and critical analysis established as a crucial element to the proposal of this 'narrador intelectual pingente', considering the aspects of mediation and values in the dialog between the two authors. For this, we use theoretical references which can provide clues about the reflections on criticisms as an intellectual, communicational, artistic and mediatic phenomena.

Keywords: Criticism. Narrador Intelectual Pingente. Lima Barreto.

\section{Resumen}

Este artículo investiga las críticas expuestas por el "narrador intelectual colgante", desde los textos literarios y periodísticos del escritor Lima Barreto (1881-1922). El eco crítico de tal examen se puede encontrar en el trabajo del escritor y periodista João Antônio (1937-1996), especialmente en el 
"Calvário e porres do pingente Afonso Henriques de Lima Barreto" (1977). Nuestro analisis busca articular dichos textos a través de la descripción, discusión e interpretación de la crítica establecida como un elemento decisivo para los objetivos de este "narrador intelectual colgante", considerando aspectos de mediación y valores culturales en el diálogo entre los dos autores. Son utilizadas referencias teóricas que ofrecen pistas sobre la reflexión crítica como un fenómeno intelectual, comunicativo y artístico.

Palabras clave: Crítica. Narrador Intelectual Pingente. Lima Barreto. 